\title{
Analisis Daya Dukung Lahan sebagai Pengembangan Fasilitas Perkotaan Kecamatan Mpunda Kota Bima Tahun 2015 - 2035
}

\author{
Rasyid Ridha ${ }^{1}$ \\ Program Studi Magister Perencanaan Pembangunan Wilayah dan Pengelolaan Lingkungan \\ Universitas Mahasarawati, Denpasar, Indonesia \\ Nyoman Utari Vipriyanti \\ Program Studi Magister Perencanaan Pembangunan Wilayah dan Pengelolaan Lingkungan \\ Universitas Mahasarawati, Denpasar, Indonesia
}

\section{IGN. Alit Wiswasta}

Program Studi Magister Perencanaan Pembangunan Wilayah dan Pengelolaan Lingkungan Universitas Mahasarawati, Denpasar, Indonesia

Artikel Masuk : 28 Maret 2016

Artikel Diterima : 27 April 2016

Tersedia Online : 30 April 2016

\begin{abstract}
Abstrak: Penelitian ini didasari oleh fenomena pembangunan di Kota Bima yang berdampak terhadap kondisi fisik wilayah serta pengembangan fasilitas yang tidak merata. Untuk itu, perlu dilakukan analisis daya dukung lahan sebagai lahan pengembangan fasilitas perkotaan Kecamatan Mpunda Kota Bima tahun 2015-2035. Tujuan penelitian ini adalah untuk menentukan daya dukung lahan Kecamatan Mpunda sebagai upaya penyediaan lahan yang sesuai untuk pengembangan fasilitas perkotaan. Analisis meliputi deskripsi kualitatif dan kuantitatif di wilayah Kecamatan Mpunda yang menjelaskan gambaran umum geografis hingga sebaranfasilitas wilayah. Metode analisis yang digunakan mengacu pada Peraturan Menteri Pekerjaan Umum No.20/PRT/M/2007 tentang Pedoman Teknik Analisis Fisik danLingkungan, dan analisis kebutuhan fasilitas pada tahun perencanaan selalu didasarkan pada kecenderunganpertumbuhan penduduk. Perhitungan proyeksi kebutuhan fasilitas atau sarana di Kecamatan Mpunda didasarkan pada SNI 03-1733-2004 tentang Tata Cara Perencanaan Lingkungan Perumahan Perkotaan dan Kebutuhan Fasilitas Lingkungan. Hasil analisis daya dukung lahan sebagai pengembangan fasilitas perkotaan Kecamatan Mpunda, yaitu dengan menetapkan kawasan lindung berdasarkan kondisi fisik. Arahan dilakukan pada kemampuan lahan kelas 4 atau kemampuan lahan rendah dan sangat rendah dengan rasio tutupan lahan hingga di tahun 2035 yaitu $0 \%$. Pengendalian pada fungsi kawasan penyangga atau kemampuan lahan kelas 3 dengan rasio tutupan lahan hingga di tahun 2035, yaitu 0\% serta masih terdapat lahan pengembangan, yaitu $20 \%$. Untuk lahan budidaya atau lahan yang sesuai untuk lahan pengembangan diarahkan pada kemampuan lahan kelas 1 dan kemampuan lahan kelas 2. Rasio tutupan lahan hingga di tahun 2035 pada kemampuan lahan
\end{abstract}

\footnotetext{
1 Korespondensi Penulis: Program Studi Magister Perencanaan Pembangunan Wilayah dan Pengelolaan Lingkungan, Universitas Mahasarawati, Denpasar, Indonesia Email: rasyidridha673@gmail.com
} 
kelas 1 telah mencapai rasio tutupan lahan maksimum, yaitu 70\%.Sedangkan rasio tutupan lahan hingga di tahun 2035 pada kemampuan lahan kelas 2, yaitu 49\% dari rasio tutupan lahan maksimum $50 \%$.

Kata Kunci: daya dukung lahan, kemampuan lahan, perencanaan fisik wilayah, fasilitas perkotaan

\begin{abstract}
This study is based on the phenomenon of development in Bima City and affects the physical condition of the region and not evenly of facilities distribution. So that, it is necessary to analyze the carrying capacity of urban area facilities development in Mpunda District, Bima City 2015-2035. The study aims to determine the carrying capacity of Mpunda District to provide a suitable area for the development of urban facilities. The analysis uses both qualitative and quantitative description in the Mpunda District to describe the general overview of geographic distribution facilities. The analytical method used is based on Public Works Minister Regulation No.20/PRT/M/2007 about Technical Guidelines for Physical \& Environmental analysis. Analysis facility needs in planning is always based on the development trend of the population. The calculation for projecting the need facilities is based on SNI 03-1733-2004 about Procedures for Environmental Planning about Housing Design in City and Need of Environmental Facilities. The analysis results of the carrying capacity of the urban area facilities development in Mpunda District is by establishing the protected areas based on the physical condition especially for class 4 of land capability which have the lowest ability with the land cover ratio in 2035 is 0\%. Controlling as the functions of the buffer zone must be done for class 3 of land capability. The development land is directed for the class 1 and class 2 as the cultivation land. There is land development, which is 20\%. For the cultivation of land or land suitable for development land directed to land capability and land capability class 1 class 2. The ratio of class 1 land coverage area in 2035 has reached the maximum land cover ratio, i.e. $70 \%$. While the ratio of class 2 land coverage area in 2035 , i.e. $49 \%$ of from the $50 \%$ maximum of land cover ratio.
\end{abstract}

Keywords: land carrying capacity, land capability, regional physical planning, urban facilities

\title{
Pendahuluan
}

Seiring dengan berkembangnya perkotaan dan meningkatnya jumlah penduduk di Kecematan Mpunda Kota Bima, kebutuhan lahan dan penyediaan fasilitas perkotaan semakin meningkat. Berdasarkan data jumlah penduduk Kecamatan Mpunda dalam kurun waktu lima tahun terakhir yang dikeluarkan oleh Badan Pusat Statistik (BPS) Kota Bima bahwa pada tahun 2010 jumlah penduduk Kecamatan Mpuda berjumlah 26.474 jiwa sedangkan di tahun 2014 berjumlah 35.648 jiwa. Ini berarti jumlah penduduk dari tahun 2010 sampai 2014 mengalami peningkatan sebesar 9.174 jiwa dengan kepadatan penduduk tahun 2014 mencapai 2333 jiwa $/ \mathrm{km}^{2}$.

Pola guna lahan di Kecamatan Mpunda berkembang secara parsial dan liner mengikuti perkembangan jaringan jalan. Perkembangan pembangunan dan pemanfaatan ruang di Kecamatan Mpunda dari tahun ke tahun memperlihatkan perkembangan yang signifikan. Kehadiran fasilitas pendidikan yang berpusat di Kecamatan ini, mulai dari tingkat dasar hingga perguruan tinggi, menambah geliat pembangunan di Kecamatan Mpunda semakin dinamis. Pemindahan pusat pemerintahan Kota Bima dari Kecamatan Raba ke Kecamatan Mpunda, merupakan salah satu faktor penyumbang dan memberi pengaruh kuat bagi perkembangan wilayah Kecamatan Mpunda.

Aspek fisik terutama kondisi topografi wilayah merupakan faktor dominan yang menyebabkan terjadinya perbedaan pola pengembangan di daerah - daerah. Berdasarkan laporan Rencana Tata Raung Wilayah Kota Bima tahun 2011 - 2031, wilayah Kecamatan 
Mpunda sendiri sebagian besar wilayahnya berada pada kemiringan $0-2 \%$ dan $3-15 \%$, yang meliputi Kelurahan Mande, Kelurahan Sadia, Kelurahan Manggemaci, Kelurahan Monggonao, Kelurahan Lewirato, Kelurahan Penatoi dan Kelurahan Santi. Wilayah yang memiliki kelerengan relatif datar tersebut, saat ini dimanfaatkan sebagai kawasan budidaya dan merupakan lahan pengembangan perkotaan. Untuk bagian Selatan, yaitu Kelurahan Panggi dan Kelurahan Saminae merupakan kawasan perbukitan yang memiliki kelerengan dominan lebih dari 40\%. Sedangkan untuk bagian Utara, yaitu di Kelurahan Matakando, didominasi oleh kelerengan yang berkisar antara $16-40 \%$. Kondisi topografi tersebut menjadi salah satu faktor fisik penghambat pengembangan lahan di wilayah Kelurahan Panggi, Kelurahan Saminae dan Kelurahan Matakando. Dampak lainnya dari aspek fisik tersebut adalah pengembangan Kecamatan Mpunda menjadi terpusat pada wilayah yang memiliki kelerengan datar 0 - 15\% sehingga pengembangan wilayah Kecamatan Mpunda tidak merata baik dari ketersediaan infrastruktur maupun fasilitas publik lainya.

Berdasarkan kondisi wilayah Kecamatan Mpunda tersebut serta mengalami peningkatan jumlah penduduk di setiap tahunnya, membutuhkan ruang sebagai lahan pengembangan permukiman dan fasilitas untuk menujang aktivitas penduduk. Namun, di sisi lain luas wilayah Kecamatan Mpunda yang relatif kecil serta memiliki faktor penghambat lainya seperti kondisi fisik khususnya di sejumlah kelurahan yang memiliki topografi dengan kelerengan yang curam. Sedangkan kecenderungan lahan pengembangan wilayah Kecamatan Mpunda terpusat pada topografi dengan kelerengan yang relatif datar. Hambatan lainnya adalah wilayah dengan topografi yang relatif datar mengalami penyusutan dari ukuran luas wilayahnya. Sebagai akibatnya lahan pengembangan semakin terbatas. Kondisi wilayah seperti ini justru sangat rentan akan terjadinya alih fungsi lahan dan pembangunan yang tidak terkendali dampak dari meningkatnya jumlah penduduk dan kurangnya lahan pengembangan. Untuk mencegah dan meminimalisir hal tersebut, maka dipelukan strategi atau penanganan yang tepat dalam peruntukan lahan di Kecamatan Mpunda secara baik, teratur, dan berkelanjutan dengan meninajau daya dukung lahan dan memproyeksikan kebutahan lahan permukiman dan fasilitas perkotaan lainnya.

Berdasarkan latar belakang di atas maka perumusan masalah dalam penelitian ini adalah sebagai berikut:

a) Bagaimanakah daya dukung lahan Kecamatan Mpunda dalam upaya penyediaan lahan yang mendukung pengembangan fasilitas perkotaan?

b) Seberapa banyakkah kebutuhan fasilitas perkotaan yang di proyeksikan sesuai dengan jumlah penduduk di Kecamatan Mpunda pada Tahun 2015-2035?

c) Bagaimana arahan rencana pengembangan fasilitas perkotaan yang sesuai dengan daa dukung lahan di Kecamatan Mpunda pada tahun 2015-2035?

Berdasarkan rumusan masalah tersebut maka dapat ditemtukan tujuan penelitian ini, yaitu:

a) Menganalisis kemampuan lahan Kecamatan Mpunda dalam upaya penyediaan lahan yang mendukung untuk pengembangan fasilitas perkotaan.

b) Menganalisis kebutuhan fasilitas perkotaan yang di proyeksikan sesuai dengan jumlah penduduk di Kecamatan Mpunda pada Tahun 2015-2035.

c) Merumuskan arahan rencana pengembangan fasilitas perkotaan yang sesuai dengan kemampuan lahan di Kecamatan Mpunda pada tahun 2015-2035.

\section{Metode Penelitian}

\section{Jenis Penelitian}

Jenis penelitian yang digunakan adalah penelitian deskriptif. Penelitian deskriptif adalah suatu bentuk penelitian yang ditujukan untuk mendeskripsikan fenomena-fenomena yang ada, baik fenomena alamiah maupun fenomena buatan manusia. Fenomena tersebut 
dapat berupa bentuk, aktivitas, karakteristik, perubahan, hubungan, kesamaan, dan perbedaan antara fenomena yang satu dengan fenomena lainnya (Sukmadinata, 2006: 72).

\section{Analisis Data}

\section{Analisis Kemampuan Lahan}

Analisis Kemampuan lahan (land capability) adalah penilaian lahan secara sistematik dan pengelompokannya ke dalam beberapa kategori berdasarkan atas sifat-sifat yang merupkan potensi dan penghambat dalam penggunaannya secara lestari. Dalam penelitian ini analisis kemampuan lahan mengacu pada Peraturan Menteri Pekerajaan Umum No.20/PRT/M/2007 tentang Pedoman Teknik Analisis Fisik \& lingkungan. Kebutuhan data dalam analisis Satuan Kemampuan Lahan (SKL), yaitu:

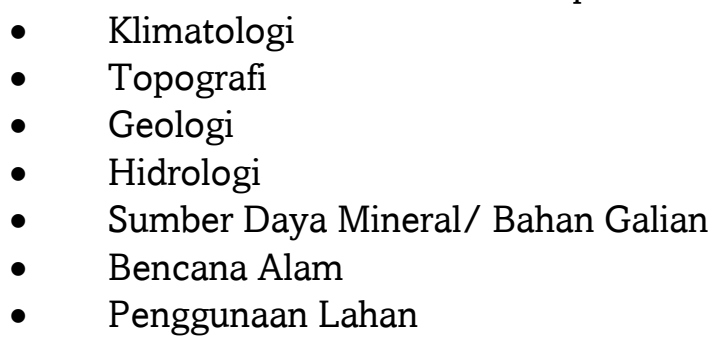

Tujuan dari analisis Satuan Kemampuan Lahan (SKL) untuk memperoleh gambaran tingkat kemampuan lahan untuk dikembangkan sebagai perkotaan dan sebagai acuan bagi arahan-arahan kesesuaian lahan. Untuk lebih jelasnya dapat dilihat pada Tabel 1 berikut.

Tabel 1. Pembobotan Satuan Kemampuan Lahan

\begin{tabular}{clc}
\hline No & \multicolumn{1}{c}{ Satuan Kemampuan Lahan } & Bobot \\
\hline 1 & SKL Morfologi & 5 \\
2 & SKL Kemudahan Dikerjakan & 1 \\
3 & SKL Kestabilan Lereng & 5 \\
4 & SKL Kestabilan Pondasi & 3 \\
5 & SKL Ketersediaan Air & 5 \\
6 & SKL Untuk Drainase & 3 \\
7 & SKL Terhadap Erosi & 5 \\
8 & SKLTerhadap Pembungan Limbah & 0 \\
9 & SKL Terhadap Bencana Alam & 5 \\
\hline Sumber: & Peraturan Menteri PU No.20/PRT/M/2007
\end{tabular}

Pembagian klasifikasi berdasarkan pembagian dari total nilai, dibuatkan beberapa kelas yang memperhatikan nilai minimum dan maksimum dari total nilai, perhitungan tersebut menggunakan rumus/formula yang dirumuskan oleh Effendi (1987), yaitu:

$$
\mathrm{I}=\mathrm{R} / \mathrm{N}
$$

Dimana:

$$
\begin{aligned}
\mathrm{I} & =\text { lebar interval } \\
\mathrm{R} & =\text { jarak interval } \\
\mathrm{N} & =\text { jumlah interval }
\end{aligned}
$$

Berdasarkan perhitungan interval tersebut, maka klasifikasi kemampuan lahan akan terbagi sesuai jarak interval nilai minimum dan maksimum seperti yang terlihat pada Tabel 2. 
Tabel 2. Klasifikasi Satuan Kemampuan Lahan

\begin{tabular}{cll}
\hline No & Kelas Kemampuan Lahan & \multicolumn{1}{c}{ Klasifikasi Pengembangan } \\
\hline 1 & Kelas A & Kemampuan Pengembangan Sangat Rendah \\
2 & Kelas B & Kemampuan Pengembangan Rendah \\
3 & Kelas C & Kemampuan Pengembangan Sedang \\
4 & Kelas D & Kemampuan Pengembangan Tinggi \\
5 & Kelas E & Kemampuan Pengembangan Sangat tinggi \\
\hline Sumber: Peraturan Menteri PU No.20/PRT/M/2007
\end{tabular}

\section{Analisis Daya Dukung Lahan}

Analisis daya dukung lahan ini mengacu pada Soerjani (1987) dan dijelaskan dalam Peraturan Menteri Negara Perumahan Rakyat Nomor: 11/PERMEN/M/2008 tentang Pedoman Keserasian Kawasan Perumahan Dan Permukiman, dengan klasifikasi daya dukung lahan berdasarkan kemampuan lahan, yaitu:

- Kemampuan lahan kelas 1 (Kemampuan Pengembangan Sangat Tinggi), ratio tutupan lahannya maksimal $70 \%$.

- Kemampuan lahan kelas 2 (Kemampuan Pengembangan Tinggi), rasio tutupan lahannya maksimal $50 \%$

- Kemampuan lahan kelas 3 (Kemampuan Pengembangan Sedang), rasio tutupan lahannya maksimal $20 \%$

- Kemampuan lahan kelas 4 (Kemampuan Pengembangan Rendah hingga Sangat Rendah), rasio tutupan lahannya $0 \%$.

Adapun rumus yang digunakan dalam menentukan daya dukung lahan berkaitan dengan penentuan Building Coverage (BC) pada suatu lokasi. Prinsip dasarnya adalah menghitung berapa besar daerah yang tetap terbuka atau dilestarikan menurut Mock (1983), yaitu:

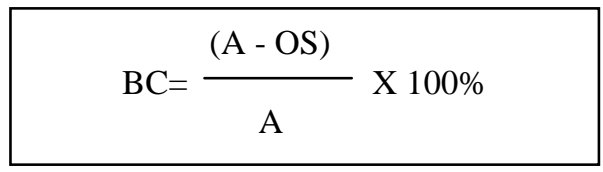

Keterangan :

$$
\begin{array}{ll}
\mathrm{BC} & =\text { Building Coverage } \\
\mathrm{A} & =\text { Area }(\text { Luas Lahan) } \\
\mathrm{OS} & =\text { Open Space (lahan tidak terbangun) }
\end{array}
$$

\section{Analisis Demografi}

Tujuan analisis proyeksi penduduk adalah untuk mengetahui perkembangan dan penambahan jumlah penduduk setiap tahunnya. Sebagai mana yang di jelaskan pada landasan teori menurut Mantra (2006), metode yang digunakan adalah metode bunga berganda atau pertumbuhan penduduk geometris yang berarti pertumbuhan bertahap dimana setiap tahun merupakan satu tahap dan diproyeksikan untuk 20 tahun kedepan. Perhitungan proyeksi menggunakan metode geometri dengan rumus sebagai berikut: 


$$
\mathrm{Pn}=\mathrm{Po}(1+\mathrm{r})^{\mathrm{n}}
$$

Keterangan :

Pn : Jumlah penduduk pada tahun ke-n

Po : Jumlah penduduk pada awal pengamatan

n : Selisih tahun (20 tahun)

$\mathrm{r} \quad$ : Prosentase (laju) pertumbuhan tiap tahun

\section{Analisis Fasilitas Perkotaan}

Analisis kebutuhan fasilitas pada tahun perencanaan selalu didasarkan pada tren perkembangan penduduk. Perhitungan proyeksi kebutuhan fasilitas atau sarana di Kecamatan Mpunda didasarkan pada SNI 03-1733-2004 tentang Tata Cara Perencanaan Lingkungan Perumahan Perkotaan, fasilitas atau sarana pokok yang dimaksud dalam SNI 03-1733-2004, yaitu:

- Permukiman/Perumahan/Hunian

- Fasilitas Pemerintahan dan Pelayanan Umum

- Fasilitas Pendidikan

- Fasilitas Kesehatan

- Fasilitas Peribadatan

- Fasilitas Perdagangan dan Jasa

- Fasilitas Kebudayaan dan Rekreasi

- Fasilitas Ruang Terbuka, Taman dan Lapangan Olah Raga

\section{Gambaran Umum}

Kecamatan Mpunda merupakan salah satu Kecamatan yang merupakan bagian dari wilayah administrasi Kota Bima. Adapun batas-batas wilayah Kecamatan Mpundai:

Sebelah Utara : Berbatasan dengan Kecamatan Asakota

Sebelah Timur : Berbatasan dengan Kecamatan Raba

Sebelah Selatan : Berbatasan dengan Wilayah Kabupaten Bima

Sebelah Barat : Berbatasan dengan Kecamatan Rasana'e Barat

Kecamatan Mpunda memiliki luas wilayah sebesar 15,28 $\mathrm{km}^{2}$ atau $1.528 \mathrm{Ha}$ yang terdiri dari 10 wilayah Kelurahan dengan luas wilayah Kecamatan Mpunda yang relatif kecil, dengan prosentase sebesar 6,86 \% dari keseluruhan luas wilayah Kota Bima yang memiliki luas wilayah seluas $222,25 \mathrm{~km}^{2}$. Untuk lebih jelasnya mengenai pembagian wilayah Kelurahan di Kecamatan Mpunda dapat dilihat pada Tabel 3.

Tabel 3. Pembagian Wilayah Kelurahan di Kecamatan Mpunda

\begin{tabular}{clccc}
\hline No. & Kelurahan & Luas $\left(\mathbf{k m}^{\mathbf{2}}\right)$ & Persentase (\%) & Jumlah Penduduk \\
\hline 1 & Lewirato & 0,49 & $3,2 \%$ & 2.202 \\
2 & Mande & 0,69 & $4,5 \%$ & 4.678 \\
3 & Manggemaci & 0,52 & $3,4 \%$ & 3.841 \\
4 & Matakando & 1,87 & $12,2 \%$ & 2.546 \\
5 & Monggonao & 0,63 & $4,1 \%$ & 5.444 \\
6 & Panggi & 3,51 & $23,0 \%$ & 2.886 \\
\hline
\end{tabular}




\begin{tabular}{clccc}
\hline No. & Kelurahan & Luas $\left(\mathbf{k m}^{\mathbf{2}}\right)$ & Persentase $\mathbf{( \% )}$ & Jumlah Penduduk \\
\hline 7 & Penatoi & 0,74 & $4,8 \%$ & 4.490 \\
8 & Sadia & 0,68 & $4,5 \%$ & 4.546 \\
9 & Sambinae & 5,43 & $35,5 \%$ & 2.681 \\
10 & Santi & 0,72 & $4,7 \%$ & 2.354 \\
& Total & $\mathbf{1 5 , 2 8}$ & $\mathbf{1 0 0 , 0 \%}$ & $\mathbf{3 5 . 4 6 8}$ \\
\hline
\end{tabular}

Sumber Data: Kecamatan Mpunda Dalam Angka, Tahun 2015

Penggunaan lahan di Kecamatan Mpunda terdiri dari tanah sawah seluas $320 \mathrm{Ha}$, lahan terbangun dan pekarangan $466 \mathrm{Ha}$, tegalan $388 \mathrm{Ha}$, hutan $116 \mathrm{Ha}$ serta peruntukan lainnya $257 \mathrm{Ha}$. Kondisi fisik wilayah Kecamatan Mpunda sebagian besar wilayahnya berada pada kelerengan $0-2 \%$ dan $3-15 \%$. Wilayah yang memiliki kelerengan tersebut saat ini merupakan wilayah yang dimanfaatkan sebagai kawasan budidaya dan merupakan lahan pengembangan perkotaan. Untuk bagian selatan wilayah meliputi Kelurahan Panggi dan Kelurahan Sambinae merupakan kawasan perbukitan dan pegunangan yang memiliki kelerengan lebih dari 40\%. Sedangkan untuk bagian utara, yaitu di Kelurahan Matakando, kelerengan wilayahnya dalam kisasran $16-40 \%$. Untuk jenis tanah di Kecamatan Mpunda didominasi oleh formasi geologi berupa tanah Aluvial (Qa) dan batuan gunung berapi tua (Tlmv). Sedangkan formasi geologi lain di Kecamatan Mpunda terdiri dari sebagian kecil wilayah dengan formasi Batuan Gamping dan Batuan Hasil Gunung Api Tua.

\section{Hasil dan Pembahasan}

\section{Analisis Kemampuan Lahan Kecamatan Mpunda}

Peraturan Menteri Pekerajaan Umum No.20/PRT/M/2007 tentang Pedoman Teknik Analisis Fisik \& Lingkungan, Ekonomi Serta Sosial Budaya Dalam Penyusunan Tata Ruang, menjelaskan kemampuan lahan merupakan bagian dari analisis aspek fisik \& lingkungan dengan pencapaian analisis sebagai lahan pada kawasan atau wilayah perencanaan merupakan sumber daya alam yang memiliki keterbatasan dalam menampung kegiatan manusia dalam pemanfaatannya, aspek analisis fisik dan lingkungan yang menjadi faktor pembanding akan dinilai dan akan menjadi acuan bagi satuan kemampuan lahan (SKL), seperti yang ditinjukan pada Tabel 4.

Tabel 4. Analisis Aspek Fisik Kecamatan Mpunda

\begin{tabular}{|c|c|c|c|c|c|c|}
\hline $\begin{array}{c}\text { Morfologi Dan } \\
\text { Kelerengan }\end{array}$ & Geologi & $\begin{array}{c}\text { Penggunaan } \\
\text { Lahan }\end{array}$ & $\begin{array}{l}\text { Hidrologi } \\
\text { Dan } \\
\text { Klimatologi }\end{array}$ & $\begin{array}{c}\text { Bencana } \\
\text { Alam }\end{array}$ & $\begin{array}{l}\text { Sumber } \\
\text { Daya } \\
\text { Mineral }\end{array}$ & Nilai \\
\hline $\begin{array}{l}\text { Gunung/ Pegunungan } \\
\text { dan bukit /Perbukitan } \\
\text { dengan tingkat } \\
\text { kelerengan }>40 \% \\
\text { Gunung/ Pegunungan } \\
\text { dan bukit /Perbukitan } \\
\text { dengan tingkat } \\
\text { kelerengan } 25-40 \%\end{array}$ & $\begin{array}{l}\text { Batuan } \\
\text { Gunung } \\
\text { api Tua } \\
\text { (Tlmv) } \\
\text { Batuan } \\
\text { hasil } \\
\text { Gunung } \\
\text { api Tua } \\
\text { (QT) }\end{array}$ & $\begin{array}{l}\text { Kebun, } \\
\text { tegalan, semak } \\
\text { belukar, hutan. }\end{array}$ & $\begin{array}{l}\text { Curah hujan } \\
\text { Kecamatan } \\
\text { Mpunda, yaitu } \\
\text { 136,33 } \\
\text { mm/tahun dan } \\
\text { dialiri } 3 \text { sungai } \\
\text { yaitu: } \\
\text { - Sungai } \\
\text { Sadia }\end{array}$ & $\begin{array}{l}\text { - Bencana } \\
\text { Gempa } \\
\text { Bumi } \\
\text { - Bencana } \\
\text { Banjir } \\
\text { - Angin } \\
\text { Puting } \\
\text { Beliung } \\
\text { - Tanah }\end{array}$ & $\begin{array}{l}\text { Bahan } \\
\text { galian } \\
\text { golongan } \\
\mathrm{C} \text { berupa } \\
\text { andesit }\end{array}$ & 2 \\
\hline $\begin{array}{l}\text { Bukit/ Perbukitan } \\
\text { dengan tingkat } \\
\text { kelerengan } 15-25 \% \\
\text { Datar dengan tingkat }\end{array}$ & $\begin{array}{l}\text { Batu } \\
\text { Gamping } \\
\text { (Tlml) } \\
\text { Alluvial }\end{array}$ & $\begin{array}{l}\text { Bagunan, } \\
\text { sawah dan } \\
\text { lainya }\end{array}$ & $\begin{array}{l}\text { - Sungai } \\
\text { Rontu } \\
\text { - Sungai } \\
\text { Ntobo }\end{array}$ & Longsor & & 4 \\
\hline
\end{tabular}


72 Analisis Daya Dukung Lahan sebagai Pengembangan Fasilitas Perkotaan Kecamatan Mpunda...

\begin{tabular}{|c|c|c|c|c|c|c|}
\hline $\begin{array}{l}\text { Morfologi Dan } \\
\text { Kelerengan }\end{array}$ & Geologi & $\begin{array}{l}\text { Penggunaan } \\
\text { Lahan }\end{array}$ & $\begin{array}{c}\text { Hidrologi } \\
\text { Dan } \\
\text { Klimatologi }\end{array}$ & $\begin{array}{l}\text { Bencana } \\
\text { Alam }\end{array}$ & $\begin{array}{c}\text { Sumber } \\
\text { Daya } \\
\text { Mineral }\end{array}$ & Nilai \\
\hline kelerengan $2-15 \%$ & $(\mathrm{Qa})$ & & & & & \\
\hline $\begin{array}{l}\text { Datar tingkat dengan } \\
\text { kelerengan } 0-2 \%\end{array}$ & $\begin{array}{l}\text { Alluvial } \\
(\mathrm{Qa})\end{array}$ & & & & & 5 \\
\hline
\end{tabular}

Sumber: Hasil analisis dan Peraturan Menteri Pekerajaan Umum No.20/PRT/M/2007

Berdasarkan hasil kajian satuan kemampuan lahan (SKL) yang mengacu pada aspek fisik di Kecamatan Mpunda diperoleh hasil total nilai kemampuan lahan dengan menggabungkan setiap item satuan kemampuan lahan dengan teknik Overlay peta SKL sehingga membentuk suatu Klasifikasi kemampuan lahan, satuan kemampuan lahan (SKL) sendiri tebagi menjadi 9 dengan nilai yang disesuaikan berdasarkan komponen fisik, separti yang di tampilkan pada Tabel 5.

Tabel 5. Nilai Kemampuan Lahan Wilayah Kecamatan Mpunda

\begin{tabular}{|c|c|c|c|c|c|c|}
\hline Kemampuan Lahan & Bobot & \multicolumn{5}{|c|}{ Bobot $x$ Nilai } \\
\hline SKL Kemudahan Morfologi & Bobot: 5 & 5 & 10 & 15 & 20 & 25 \\
\hline SKL Kemudahan Dikerakkan & Bobot: 1 & 1 & 2 & 3 & 4 & 5 \\
\hline SKL Kestabilan Lereng & Bobot : 5 & 5 & 10 & 15 & 20 & 25 \\
\hline SKL Kestabilan Pondasi & Bobot : 3 & 3 & 6 & 9 & 12 & 15 \\
\hline SKL Ketersediaan Air & Bobot : 5 & 5 & 10 & 15 & 20 & 25 \\
\hline SKL Untuk Drainase & Bobot : 3 & 3 & 6 & 9 & 12 & 15 \\
\hline SKL Terhadap Erosi & Bobot : 5 & 3 & 6 & 9 & 12 & 15 \\
\hline SKLTerhadap Pembungan Limbah & Bobot : 0 & 0 & 0 & 0 & 0 & 0 \\
\hline SKL Terhadap Bencana Alam & Bobot : 5 & 5 & 10 & 15 & 20 & 25 \\
\hline Total Nilai (Overlay Peta) & & \multicolumn{5}{|c|}{$\begin{array}{c}\text { Nilai Minimum: } 32 \\
\text { Nilai Maksimum : } 169\end{array}$} \\
\hline
\end{tabular}

Hasil Overlay peta satuan kemampuan lahan di peroleh nilai minimum adalah 32 dan nilai maksimum yang di peroleh adalah 169 dan nilai interval 33,8. Dengan demikian, klasifikasi kemampuan lahan dari nilai interval diperoleh hasil yang dirincikan pada Tabel 6.

Tabel 6. Klasifikasi Pengembangan Lahan Wilayah Kecamatan Mpunda

\begin{tabular}{cllc}
\hline Total Nilai & $\begin{array}{c}\text { Kelas Kemampuan } \\
\text { Lahan }\end{array}$ & \multicolumn{1}{c}{ Klasifikasi Pengembangan } & Luas (Ha) \\
\hline $0-33,8$ & Kelas a & Kemampuan Pengembangan Sangat Rendah & 8,39 \\
$33,8-67,6$ & Kelas b & Kemampuan Pengembangan Rendah & 171,98 \\
$67,6-101,4$ & Kelas c & Kemampuan Pengembangan Sedang & 523,90 \\
$101,4-135,2$ & Kelas d & Kemampuan Pengembangan Tinggi & 296,97 \\
$135,2-169$ & Kelas e & Kemampuan Pengembangan Sangat Tinggi & 654,13 \\
\hline
\end{tabular}

Keseluruhan analisis kemampuan lahan untuk pengembangan di wilayah Kecamatan Mpunda menghasilkan klasifikasi kemampuan lahan pada kawasan budidaya untuk pengembangan kawasan permukiman dan fasiltas penunjang perkotaan yang terdiri dari:

- Kemampuan Pengembangan sangat Tinggi dan Tinggi yaitu lahan yang mempunyai kemampuan baik dan sangat sesuai untuk pengembangan Kecamatan Mpunda. 
- Kemampuan Pengembangan Sedang yaitu kemampuan lahan yang kurang mampu dikembangkan atau sesuai bersyarat apabila tetap akan dikembangkan Kecamatan Mpunda.

- Kemampuan Pengembangan Sangat Rendah dan Rendah yaitu kemampuan lahan yang tidak sesuai dikembangkan Kecamatan Mpunda.

Gambar 1 menunjukkan Peta Satuan Kemampuan Lahan Kecamatan Mpunda.

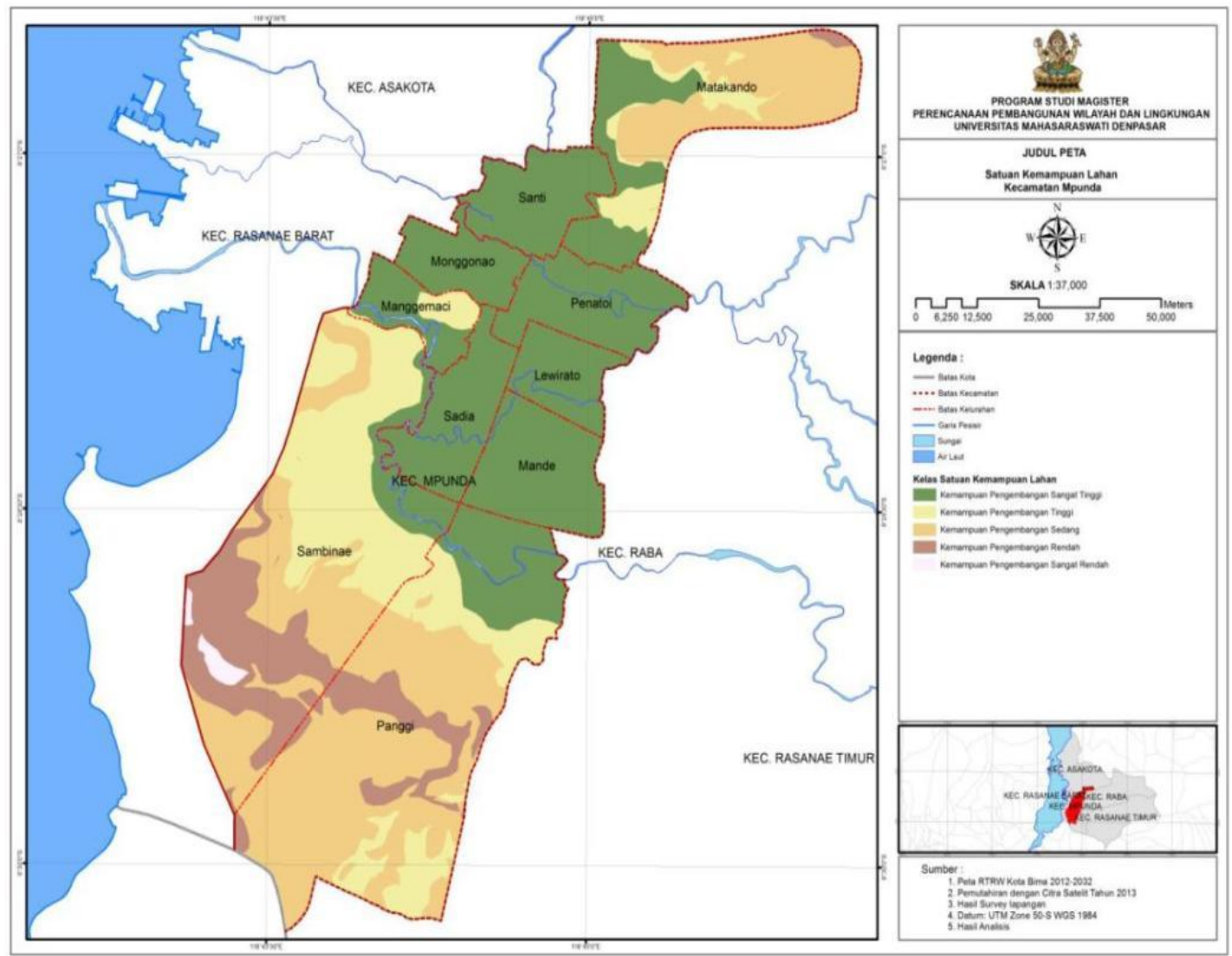

Gambar 1. Peta Satuan Kemampuan Lahan Kecamatan Mpunda

\section{Analisis Daya Dukung Lahan}

Konsep daya dukung lahan yang baik akan tercapai apabila maksimal lahan terbangun atau Building Coverage (BC) tidak melebihi 70\% dari keseluruhan lahan yang dapat digunakan di wilayah kemampuan pengembangan sangat tinggi sedangkan di wilayah kemampuan pengembangan rendah hingga sangat rendah maksimal lahan terbangun atau Building Coverage (BC), yaitu 0\%, Berdasarkan perhitungan analisis daya dukung lahan yang telah dilakukan pada Kecamatan Mpunda di peroleh hasil yaitu (lihat Gambar 2):

- $\quad$ Kelas I merupakan kemampuan lahan sangat tinggi (kawasan pengembangan) pada wilayah Kecamatan Mpunda dengan luas lahan 654,13 Ha dengan 350,81 $\mathrm{Ha}$ diantaranya merupakan lahan tidak terbangun. Dengan ketetapan ratio tutupan lahannya maksimal $70 \%$ dan 30\% lainnya di tetapkan sebagai lahan terbuka. 
74 Analisis Daya Dukung Lahan sebagai Pengembangan Fasilitas Perkotaan Kecamatan Mpunda...

$$
\begin{aligned}
\mathrm{Bc} & =\frac{654,13 \times 350,81}{654,13} \times 100 \% \\
& =43 \%
\end{aligned}
$$

Berdasarkan hasil perhitungan rasio tutupan eksisting pada kemampuan lahan kelas 1 di Kecamatan Mpunda yaitu 43\% atau 267,23 Ha, maka untuk lahan pengembangan yang dapat di manfaatkan yaitu $27 \%$ atau $165,40 \mathrm{Ha}$ dan lahan seluas $185,41 \mathrm{Ha}$ atau $30 \%$ diitetapkan sebagai ruang terbuka.

- Kelas 2 merupakan kemampuan lahan tinggi (kawasan kendala I) pada wilayah Kecamatan Mpunda dengan luas lahan 290.76 Ha dan 259.90 diantaranya lahan tidak terbangun. Dengan rasio tutupan lahannya maksimal 50\% dan $50 \%$ yang tersisa di tetapkan sebagai lahan terbuka.

$$
\begin{aligned}
\mathrm{Bc} & =\frac{290,76 \times 259,90}{290,76} \times 100 \% \\
& =11 \%
\end{aligned}
$$

Hasil Perhitungan rasio tutupan eksisting pada kemampuan lahan kelas 2 di Kecamatan Mpunda yaitu $11 \%$ atau 30,86 Ha, untuk lahan pengembangan yang dapat di manfaatkan yaitu $39 \%$ atau 114,51 Ha dan lahan tersisa seluas 114,52 atau $50 \%$ dari total keseluhan wilayah kemampuan lahan kelas 2 ditetapkan sebagai ruang terbuka.

- $\quad$ Kelas 3 merupakan kemampuan lahan sedang (kawasan kendala II) pada wilayah Kecamatan Mpunda dengan luas lahan 522,20 Ha. Dengan rasio tutupan lahannya maksimal $20 \%$ dan $80 \%$ di tetapkan sebagai lahan terbuka.

$$
\begin{aligned}
\mathrm{Bc} & =\frac{522,20 \times 522,20}{522,20} \times 100 \% \\
& =0 \%
\end{aligned}
$$

Rasio tutupan eksisting yang di hitung pada kemampuan lahan kelas 3 di Kecamatan Mpunda, yaitu $0 \%$ atau belum dimanfaatkan sebagai lahan terbangun. Untuk lahan pengembangan yang dapat dimanfaatkan tersisa yaitu $20 \%$ atau $104,44 \mathrm{Ha}$, sedangkan Namun pemanfaatan lahan pada kemampuan lahan dengan klasifikasi sedangkan $80 \%$ atau kelas 3 dapat di manfaatkan dengan bersyarat selama tidak merusak atau mengubah fungsi kawasan dan atas asas kepentingan publik.

- Kelas 4 merupakan kemampuan lahan rendah dan sangat rendah pada wilayah Kecamatan Mpunda dengan luas lahan 180,38 Ha. Untuk rasio tutupan lahannya 0\% atau ditetapkan sebaga kawasan lindung atau limitasi.

$$
\begin{aligned}
\mathrm{Bc} & =\frac{180,38 \times 180,38}{180,38} \times 100 \% \\
& =0 \%
\end{aligned}
$$

Berdasarkan hasil perhitungan rasio tutupan lahan eksisting kelas kemapuan lahan 4 yaitu $0 \%$, yang artinya keseluruhan lahan kemampuan lahan kelas 4 merupakan lahan terbuka dan ditetapkan sebagai kawasan lindung atau limitasi. 


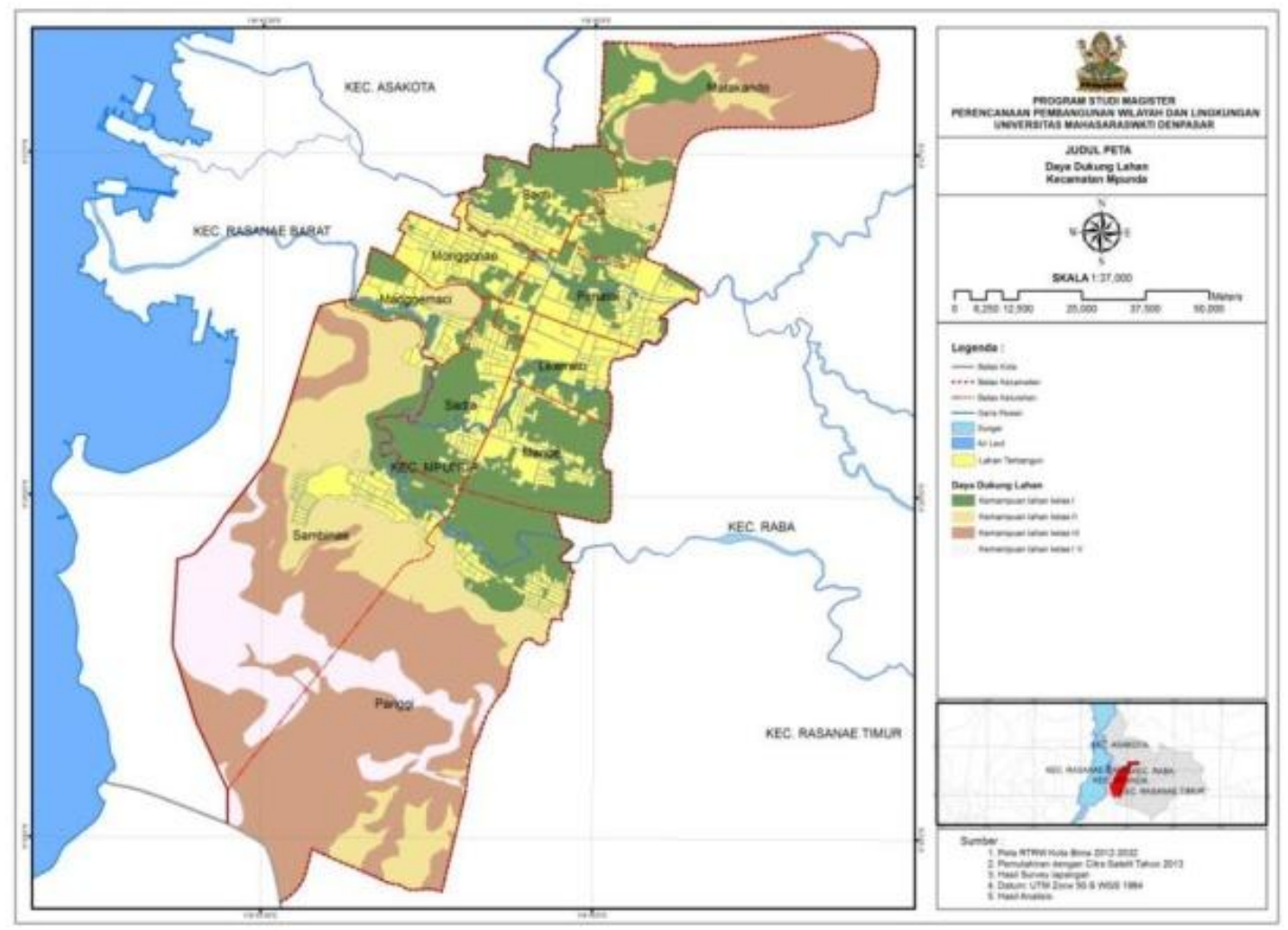

\section{Gambar 2. Peta Daya Dukung Lahan Kecamatan Mpunda}

\section{Analisis Penduduk}

Berdasarkan perhitungan analisis demografi Kecamatan Mpunda dari tahun 2015 2035 diperoleh hasil, yaitu meningkatnya jumlah penduduk yang merata di setiap Kelurahan di Kecamatan Mpunda. Rata-rata pertumbuhan penduduk pertahun, yaitu 0,069\% dengan jumlah penduduk tahun 2035 mengalami peningkatan sebanyak 136.167 jiwa dari jumlah penduduk di tahun 2014, yaitu 35.648.

- $2015=35.648(1+0,039)^{1}=38.119$ jiwa

- $2020=35.648(1+0,039)^{5}=49.836$ jiwa

- $2025=35.648(1+0,039)^{10}=69.671$ jiwa

- $2030=35.648(1+0,039)^{15}=97.401$ jiwa

- $2035=35.648(1+0,039)^{20}=136.167$ jiwa

Meningkatnya jumlah penduduk di setiap kelurahan berdampak pada meningkatnya jumlah penduduk tingkat Kecamatan. Pada tahun 2015, jumlah penduduk di Kecamatan Mpunda sebanyak 38.119 jiwa dengan luas wilayah Kecamatan Mpunda 15,28 km², maka kepadatan penududuk di Kecamatan Mpunda, yaitu $2.495 \mathrm{jiwa} / \mathrm{km}^{2}$. Sedangkan pada tahun 2035 mengalami peningkatan sebanyak 136.167 jiwa dengan tingkat kepadatan 8.911 jiwa $/ \mathrm{km}^{2}$. Gambar 3 menunjukkan laju pertumbuhan penduduk Kecamatan Mpunda tahun $2015-2035$. 
76 Analisis Daya Dukung Lahan sebagai Pengembangan Fasilitas Perkotaan Kecamatan Mpunda...

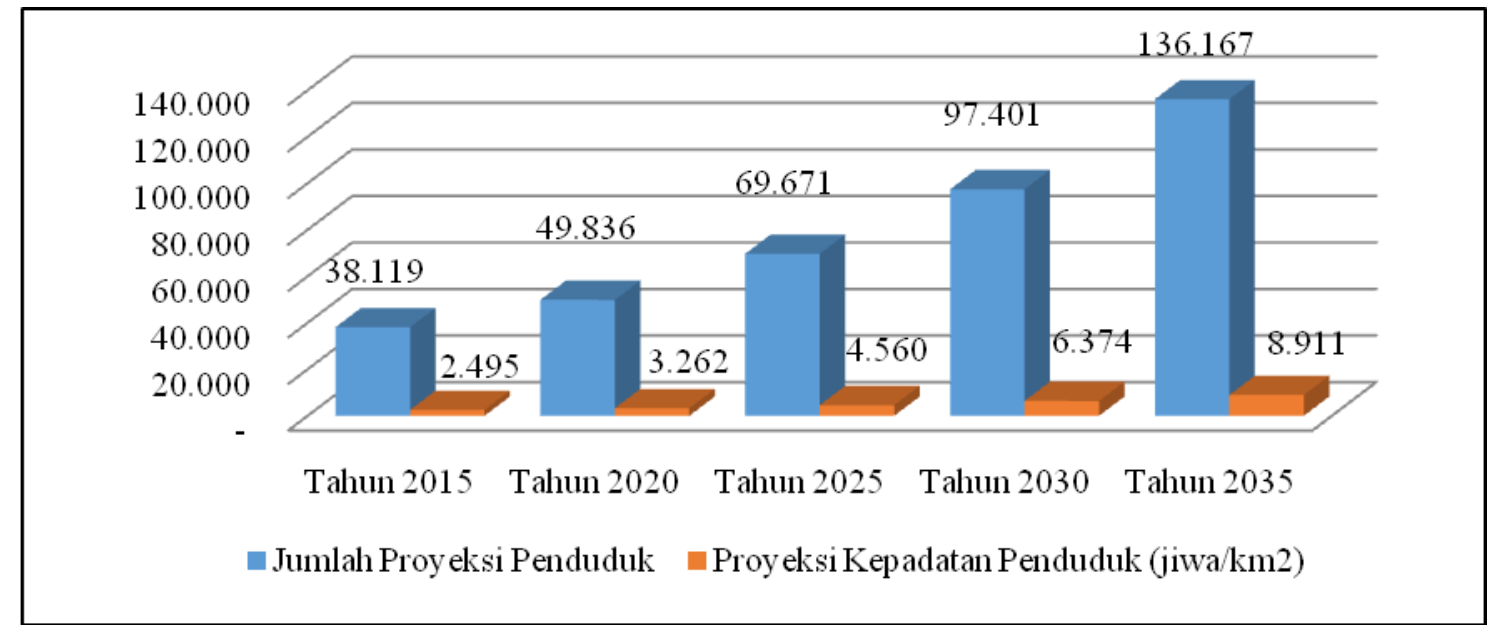

\section{Gambar 3. Laju Pertumbuhan Penduduk Kecamatan Mpunda Tahun 2015 - 2035}

\section{Analisis Kebutuhan Fasilitas dan Pemukiman}

Berdasarkan SNI 03-1733-2004 tentang Tata Cara Perencanaan Lingkungan Perumahan Perkotaan, proyeksi kebutuhan fasilitas dan permukiman akan mengikuti trend atau kecenderungan pertumbuhan penduduk yang telah dianalisis mulai tahun 2015-2035 di wilayah Kecamatan Mpunda, maka di perolehasil luas kebutuhan lahan untuk pengembangan fasilitas dan permukiman yang akan direncanakan, total luas lahan yang dibutuhkan untuk pengembangan fasilitas dan Permukiman mencapai 807.75 Ha pada tahun 2035 sedangkan di tahun 2015 luas lahan fasilitas dan permukiman hanya mencapai $333.14 \mathrm{Ha}$ atau meningkat $474.61 \mathrm{Ha}$ di tahun 2035. Untuk lebih jelasnya mengenai kebutuhan lahan pengembangan fasiltas dapat dilihat pada Gambar 4 berikut.

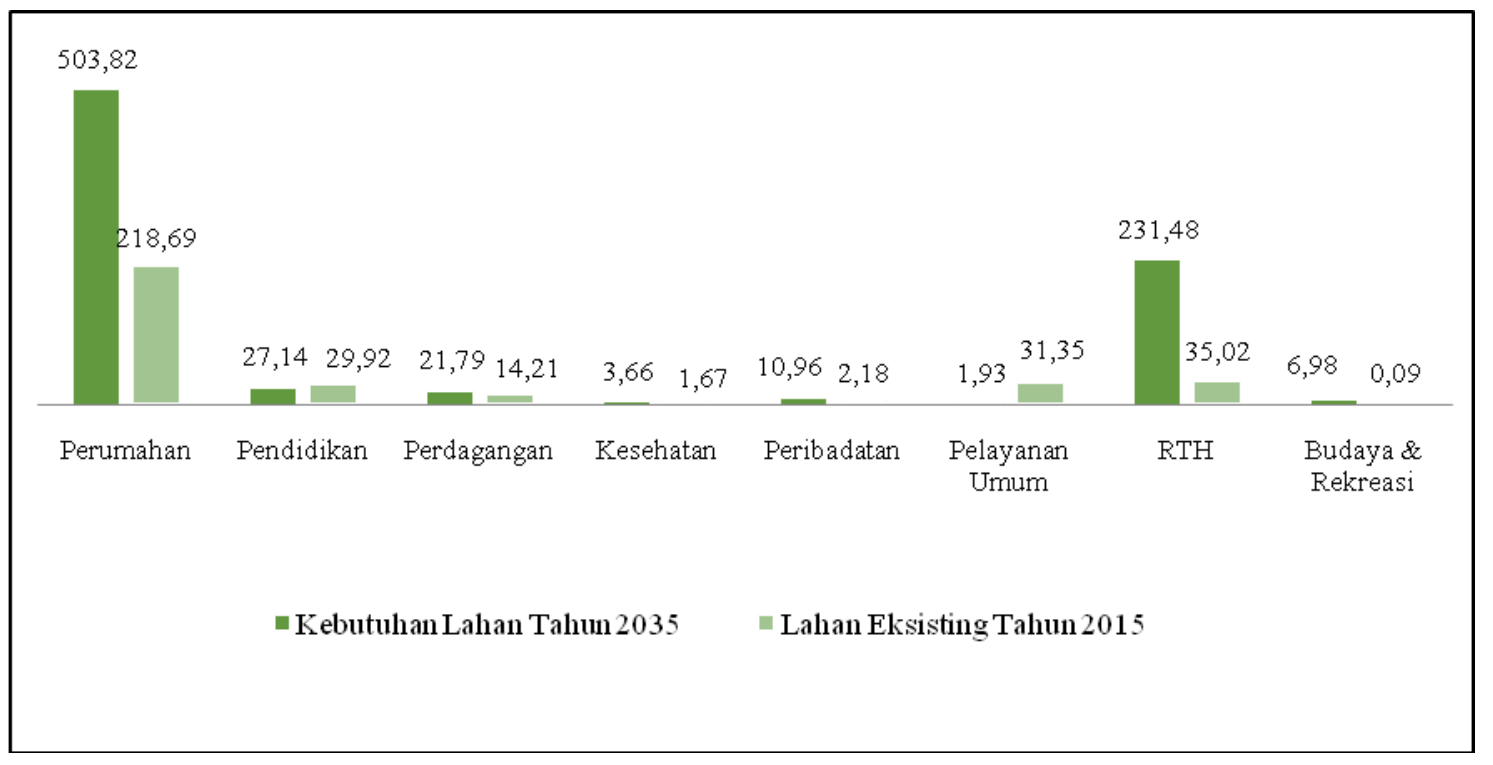

Gambar 4. Luas Kebutuhan Lahan Pengembangan Kecamatan Mpunda 
Berdasarkan hasil proyeksi di tahun 2035, luas kebutuhan lahan untuk fasilitas pendidikan serta fasilitas pemerintahan dan pelayanan umum mengalami penurunan pada luas lahan jika dibandingkan tahun 2015. Hal ini di pengaruhi dengan adanya sarana pendidikan perguruan tinggi dan Fasilitas pemerintahan dan pelayanan umum skala kota di Kecamatan Mpunda yang tidak termasuk dalam hitungan proyeksi. Namun demikian, kebutuhan lahan untuk fasilitas perumahan dan RTH di Kecamatan Mpunda di tahun 2035 diproyeksikan mengalami kenaikan yang cukup signifikan.

\section{Arahan Rencana Pengembangan Fasilitas Perkotaan Berdasarkan Daya Dukung Lahan di Kecamatan Mpunda}

\section{a) Arahan Fungsi Kawasan Lindung Kecamatan Mpunda}

Pengelolaan kawasan lindung meliputi perencanaan, pemanfaatan dan pengendalian ruang. Kegiatan perencanaan mencakup penetapan batas-batas kawasan yang berfungsi lindung pada Kecamatan Mpunda. Ketetapan kawasan lindung secara fisik diarahkan pada kawasan dengan kemampuan lahan kelas 4 atau kemampuan lahan rendah dan sangat rendah pada wilayah. Kecamatan Mpunda yang memiliki kemampuan lahan kelas 4 dengan luas lahan 180,38 Ha, ditetapkan sebaga kawasan lindung atau limitasi yang terdapat di Kelurahan Panggi, Kelurahan Sambinae dan Kelurahan Matakando.

\section{b) Arahan Fungsi Kawasan Penyangga Kecamatan Mpunda}

Penetapan dan pengendalian kawasan penyangga di Kecamatan Mpunda, meliputi kawasan dengan kemampuan lahan kelas 3 atau kemampuan lahan sedang, dengan luas kawasan penyangga di wilayah Kecamatan Mpunda yaitu 522,20 Ha. Sedangkan ketetapan pemanfaatan lahan yang dapat dikembangkan pada kemampuan lahan kelas 3 yaitu 20\% dari total keseluruhan luas kawasan penyangga atau 104,44 Ha. Namun secara fisik kawasan perlu dilakukan pengendalian terhadap pemanfaatan lahan dengan memberikan syarat dan ketentuan agar tidak merusak fungsi kawasan penyangga. Kawasan penyangga di Kecamatan Mpunda yang meliputi Kelurahan Panggi, Kelurahan Sambinae dan Kelurahan Matakando.

\section{c) Arahan Fungsi Kawasan Budidaya Kecamatan Mpunda}

Rencana pemanfaatan lahan kawasan budidaya yang ditetapkan sebagai arahan di Kecamatan Mpunda dirumuskan pada kemampuan lahan kelas 1 dan kemampuan lahan kelas 2 atau kemampuan lahan sangat tinggi dan kemampuan lahan tinggi yang terdapat diseluruh Kelurahan di Kecamatan Mpunda.

Gambar 5 menunjukkan diagram mengenai tingkat daya dukung lahan di Kecamatan Mpunda pada tahun 2015 hingga 2035. Dari grafik di gambar 5 terlihat bahwa Kecamatan Mpunda memiliki kemampuan pengembangan sangat tinggi dan tinggi. Hal ini menunjukkan bahwa secara fisik kawasan budidaya sangat mendukung dan sesuai dimanfaatkan sebagai lahan pengembangan permukiman dan faslitas perkotaan.

Kemampuan lahan kelas 1 memiliki luas, yaitu $654.13 \mathrm{Ha}$. Namun lahan yang dapat dimanfaatkan pada kemampuan lahan kelas 1, yaitu 432,63 $\mathrm{Ha}$ atau $70 \%$ dari luas keseluruhan kemampuan lahan kelas 1 . Sedangkan 30\% lahan yang tersisa seluas 185,41 Ha akan ditetapkan sebagai lahan terbuka.

Pada tahun 2035, berdasarkan hasil proyeksi dan analisis daya dukung lahan untuk kemampuan lahan kelas 1 mengalami peningkatan hingga 70\% yang berarti kemampuan lahan kelas 1 telah mencapai rasio tutupan maksimal. Kemampuan lahan kelas 2 atau 


\section{Analisis Daya Dukung Lahan sebagai Pengembangan Fasilitas Perkotaan Kecamatan Mpunda . . .}

kemampuan lahan tinggi merupakan bagian dari kawasan budidaya dengan luas keseluruhan lahan yaitu 290,76 Ha.

Adapun luas lahan yang dapat dimanfaatkan yaitu 145,38 Ha atau 50\% dari total keseluruhan kemampuan lahan kelas 2. Sedangkan 50\% lahan yang tersisa atau 145,38 Ha akan di tetapkan sebagai lahan terbuka. Pemanfaatan lahan pada kemampuan lahan kelas 2 hingga pada tahun 2035 mengalami peningkatan sebesar 49\% atau 143,63 Ha.

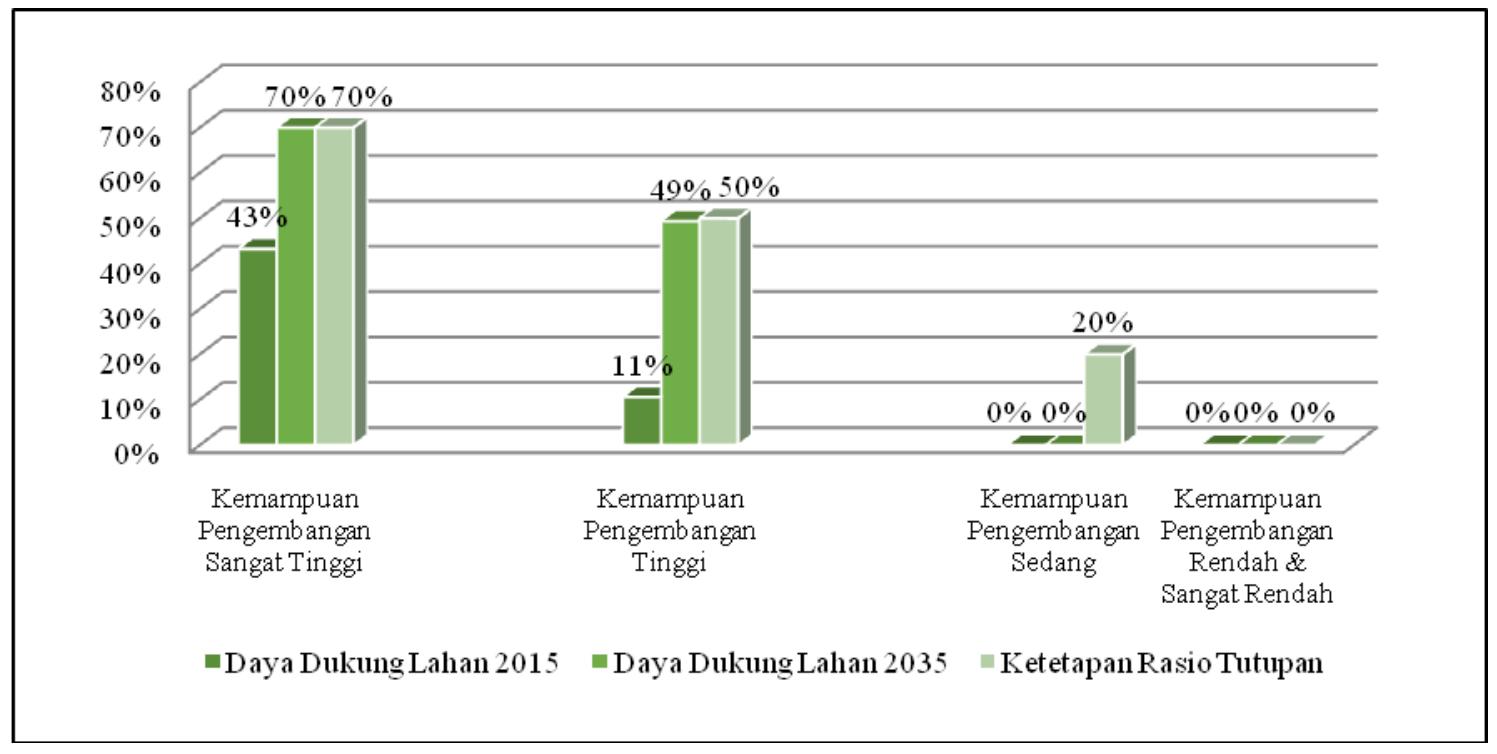

Gambar 5. Daya Dukung Lahan Kecamatan Mpunda Tahun 2015 - 2035

Gambar 6 menunjukkan peta rencana penggunaan lahan berdasarkan daya dukung lahan. Dari peta rencana penggunaan lahan berdasarkan daya dukung lahan di Kecamatan Mpunda memperlihatkan bahwa bagian selatan dan utara Kecamatan Mpunda memiliki arahan sebagai kawasan lindung, meliputi Kelurahan Panggi, Kelurahan Sambinae dan Kelurahan Matakando. Sementara itu, arahan pengembangan sebagai kawasan budidaya, cenderung terkonsentrasi di bagian tengah, seperti di Kecamatan Mande, Lewitaro, Monggonao, Penatoi, Santi, dan Manggemaci. 


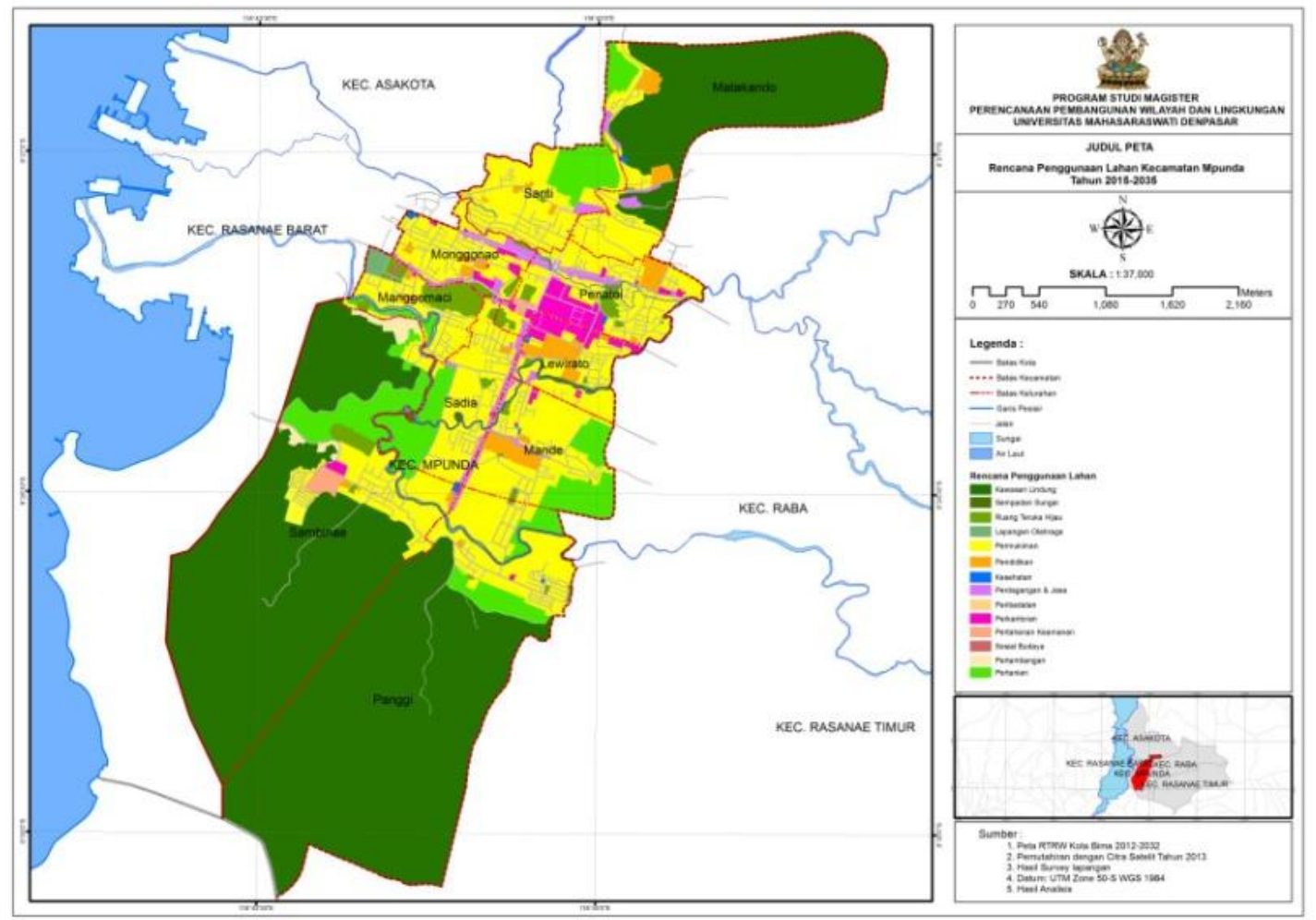

Gambar 6. Peta Rencana Penggunaan Lahan Kecamatan Mpunda Tahun 2035

\section{Kesimpulan}

Berdasarkan pembahasan tentang analisis daya dukung lahan sebagai pengembangan fasiltas perkotaan Kecamatan Mpunda Kota Bima tahu 2015-2035 yang telah diuraikan dari bab-bab sebelumnya, maka selanjutnya akan diberikan beberapa kesimpulan yang antara lain sebagai berikut:

1. Hasil analisis menunjukkan bahwa daya dukung lahan Kecamatan Mpunda di tahun 2015, untuk kebutuhan lahan hingga 2035 terbagi menjadi 4 bagian yaitu Kemampuan lahan kelas I dengan luas $654,13 \mathrm{Ha}$, dimana seluas $27 \%$ diantaranya masih dapat dikembangankan. Kemampuan lahan kelas II dengan luas 290,76 Ha, seluas 39\% lahannya yang masih dapat di kembangkan. Kemampuan lahan kelas III dengan luas lahan 522,20 $\mathrm{Ha}$, luas lahan yang tersisa hanya $20 \%$ dan untuk pengembangan memiliki syarat dan ketentuan, Kemampuan lahan kelas IV dengan laus lahan 180,38 Ha, ditetapkan sebagai kawasan lindung atau limitasi.

2. Berdasarkan hasil proyeksi kebutuhan fasilitas dan permukiman yang sudah dianalisis mulai tahun 2015 hingga 2035 di wilayah Kecamatan Mpunda, maka dapat diproyeksikan kebutuhan lahan untuk pengembangan fasilitas dan permukiman yang direncanakan, total luas lahan yang dibutuhkan untuk pengembangan fasilitas dan Permukiman mencapai 646,34 Ha pada tahun 2035 sedangkan di tahun 2015 luas kebutahan lahan hanya mencapai 333,14 Ha, atau meningkat 313,20 $\mathrm{Ha}$.

3. Arahan rencana daya dukung lahan Kecamatan Mpunda adalah dengan menetapkan kawasan lindung. Berdasarkan kondisi fisik, kawasan lindung ini diarahkan pada kawasan dengan kemampuan lahan kelas 4 atau kemampuan lahan rendah dan sangat rendah. Pengendalian pada fungsi kawasan penyangga dengan memberikan membatasan, syarat dan ketentuan pemanfaatan lahan. Kawasan penyangga di 
80 Analisis Daya Dukung Lahan sebagai Pengembangan Fasilitas Perkotaan Kecamatan Mpunda ...

maksudkan pada kemampuan lahan kelas 3. Untuk lahan budidaya atau lahan yang sesuai sebagai lahan pengembangan di arahkan pada kemampuan lahan kelas 1 dan kemampuan lahan kelas 2 .

\section{Daftar Pustaka}

Badan Standarisasi Nasional. (2004). SNI 03-1733-2004 tentang Tata Cara Perencanaan Lingkungan Perumahan di Perkotaan. Jakarta: Badan Standarisasi Nasional Republik Indonesia.

Effendi, S., \& Singarimbun, M. (1987). Metode penelitian survei. Jakarta: LP3ES.

Kementerian Negara Perumahan Rakyat Republik Indonesia. (2008). Peraturan Menteri Negara Perumahan Rakyat Nomor: 11/PERMEN/M/2008 tentang Pedoman Keserasian Kawasan Perumahan dan Permukiman. Jakarta: Kementerian Negara Perumahan Rakyat Republik Indonesia.

Mantra, B. I. (2006). Demografi umum. Yogyakarta: Pustaka Pelajar Offset.

Menteri Pekerjaan Umum Republik Indonesia. (2007). Peraturan Menteri Pekerjaan Umum Nomor: 20/PRT/M/2007 tentang Pedoman Teknik Analisis Aspek Fisik \& Lingkungan, Ekonomi serta Sosial Budaya dalam Penyusunan Rencana Tata Ruang, Jakarta. Jakarta: Kementerian Pekerjaan Umum Republik Indonesia.

Mock, F. J. (1973). Land capability appraisal Indonesia. Bogor: United Nation Development Programme, Food and Agriculture of the United Nation.

Soerjani, M., Ahmad, R., \& Munir, R. (1987). Lingkungan: Sumberdaya alam dan kependudukan dalam pembangunan. Jakarta: UI Press.

Sukmadinata. (2006). Metode penelitian pendidikan. Bandung: Remaja Rosdakarya. 